\title{
O-CHROMOSOME LETHAL FREQUENCIES IN SERBIAN AND MONTENEGRIN Drosophila subobscura POPULATIONS
}

\author{
(C) 2011 G. Zivanovic' 1 , C. Arenas ${ }^{2}$, F. Mestres ${ }^{3}$ \\ ${ }^{1}$ Department of Genetics, Institute for Biological Research 'Sinisa Stankovic', University of Belgrade 11000, Serbia \\ e-mail: goranziv@ibiss.bg.ac.rs \\ ${ }^{2}$ Departament d'Estadística, Universitat de Barcelona, Barcelona 08071, Spain \\ ${ }^{3}$ Departament de Genètica, Universitat de Barcelona, Barcelona 08071, Spain \\ Received January 27, 2011
}

\begin{abstract}
Lethal chromosomal frequencies were obtained from three Drosophila subobscura samples from the Mt. Avala (Serbia) population in September 2003 (0.218), June 2004 (0.204) and September 2004 (0.250). These values and those from other Balkan populations studied previously (Petnica, Kamariste, Zanjic and Djerdap) were used to analyze the possible effect of population, year, month and altitude above sea level on lethal chromosomal frequencies. According to ANOVAS no effect were observed. Furthermore, the lethal frequencies of the Balkan populations did not vary according to latitude. This is probably due to the relative proximity and high gene flow between these populations. From a joint study of all the Palearctic $D$. subobscura populations so far analyzed, it can be deduced that the Balkan populations are located in the central area of the species distribution. Finally, it seems that lethal chromosomal frequencies are a consequence of the genetic structure of the populations.
\end{abstract}

From late 1930, lethal genes have been used as genetic markers to detect concealed variation in Drosophila populations [1-4]. In order to study lethal genes a lethal balanced strain is required. This strain is a genetic construction involving a pair of homologous chromosomes with the following characteristics: they have to contain natural or induced chromosomal inversions to block recombination, dominant markers to detect each balanced chromosome and recessive lethal genes to prevent the homokaryotypic combination of these balanced chromosomes. Usually, the dominant genes are also recessive lethals to combine the last two genetic characteristics in only one gene. There are a limited number of Drosophila species in which lethal balanced strains are available (for instance, D. melanogaster, D. willistoni, D. prosaltans, D. pseudoobscura, D. persimilis and D. subobscura) [5]. To obtain lethal frequencies in a natural population, appropriate crosses have to be carried out with the lethal balanced strain (for instance see [5, 6]). In a population, the frequency of lethal genes is a good measure of its genetic variability. With this procedure it has been possible to study the spatial patterns of these frequencies [7-11], the annual variation within the same population [12-14] and even seasonal effects [14-16].

In $D$. subobscura, studies of lethal genes have been possible since Sperlich constructed the Va/Ba (Varicose/Bare) balanced lethal strain $[17,18]$, in which many molecular markers have recently been characterized [19]. Most analyses have focused on the geographical distribution of lethal frequencies, both in Palearctic and American populations (see [5] for a re- view). In general, it is accepted that the populations situated in the central area of the D. subobscura distribution in the Palearctic region have a higher frequency of lethal genes than marginal populations. Thus, the Spanish, Italian, Austrian, Greek and Balkan populations studied to date can be considered as central, while Scandinavian, Scottish and Tunisian populations are marginal [5]. American colonizing populations have a low frequency of lethal genes, a consequence of the strong founder effect [5].

The current study focuses on the lethal frequencies in the Balkan region, using new samples and other previously analyzed collections from this region. These results will be compared with those obtained in the Palearctic region in an attempt to identify the mechanisms that affect lethal frequency variation.

\section{MATERIALS AND METHODS}

New D. subobscura collections were obtained from Avala Mountain $\left(44^{\circ} 48^{\prime} \mathrm{N}\right)$, situated approximately $18 \mathrm{~km}$ south of Belgrade (Serbia). Flies were sampled in September of 2003, 2004 [20] and June of 2004 [21] from a forest with polydominant communities of Fagetum submontanum mixtum approximately $450 \mathrm{~m}$ above sea level [20]. Other previously collected Balkan D. subobscura populations that were used in the present study were from: Petnica, Kamariste, Zanjic and Djerdap. The environmental conditions and the trapping dates at these localities are described in $[22,23]$. 
Table 1. Lethal frequencies (as a percentage) of Balkan populations. Information on location (longitude and latitude), month and year of capture, habitat and altitude above sea level is provided for each population

\begin{tabular}{|c|c|c|c|c|c|c|c|c|}
\hline Population & Latitude/longitude & Year & Month & Habitat & Altitude & $\mathrm{N}$ & $\begin{array}{l}\text { Lethal fre- } \\
\text { quencies }\end{array}$ & References \\
\hline Petnica & $44^{\circ} 14^{\prime} \mathrm{N} / 19^{\circ} 55^{\prime} \mathrm{E}$ & 1995 & May-June & 1 & $250-300 \mathrm{~m}$ & 82 & 21.9 & {$[22]$} \\
\hline Kamariste & $45^{\circ} 28^{\prime} \mathrm{N} / 19^{\circ} 3^{\prime} \mathrm{E}$ & 1996 & June & 2 & $\sim 80$ & 85 & 27.1 & [22] \\
\hline Zanjic & $42^{\circ} 24^{\prime} \mathrm{N} / 18^{\circ} 37^{\prime} \mathrm{E}$ & 1997 & June & 3 & Sea level & 70 & 25.7 & {$[22]$} \\
\hline Djerdap & $44^{\circ} 37^{\prime} \mathrm{N} / 22^{\circ} 6^{\prime} \mathrm{E}$ & 2001 & June & 4 & $\sim 300 \mathrm{~m}$ & 58 & 32.8 & {$[23]$} \\
\hline Djerdap & $44^{\circ} 37^{\prime} \mathrm{N} / 22^{\circ} 6^{\prime} \mathrm{E}$ & 2001 & August & 4 & $\sim 300 \mathrm{~m}$ & 25 & 28.0 & [23] \\
\hline Djerdap & $44^{\circ} 37^{\prime} \mathrm{N} / 22^{\circ} 6^{\prime} \mathrm{E}$ & 2002 & June & 4 & $\sim 300 \mathrm{~m}$ & 69 & 26.1 & [23] \\
\hline Avala & $44^{\circ} 48^{\prime} \mathrm{N} / 20^{\circ} 27^{\prime} \mathrm{E}$ & 2003 & Sept. & 5 & $\sim 450 \mathrm{~m}$ & 23 & 21.8 & $*$ \\
\hline Avala & $44^{\circ} 48^{\prime} \mathrm{N} / 20^{\circ} 27^{\prime} \mathrm{E}$ & 2004 & June & 5 & $\sim 450 \mathrm{~m}$ & 49 & 20.4 & $*$ \\
\hline Avala & $44^{\circ} 48^{\prime} \mathrm{N} / 20^{\circ} 27^{\prime} \mathrm{E}$ & 2004 & Sept. & 5 & $\sim 450 \mathrm{~m}$ & 8 & 25.0 & $*$ \\
\hline
\end{tabular}

Note: $N$, sample size; *, current study. Habitats: 1, dense horn-beam woodland (Carpinus betulus); 2, locust tree (Robinia pseudoacacia) and poplar (Populus alba) forest; 3, olive grove (Olea europaea); 4, fago-colurnetum mixtum polydominant communities; 5, forest with polydominant communities of Fagetum submontanum mixtum.

Drosophila subobscura O-chromosome lethal genes were obtained by carrying out appropriate crosses with the $\mathrm{Va} / \mathrm{Ba}$ balanced lethal strain. The pattern of crosses used is described in detail in [24], however, we would like to explain briefly this pattern of crosses. Wild males were crossed in individual vials with $2-3$ $\mathrm{Va} / \mathrm{Ba}$ virgin females. A single $\mathrm{F}_{1} \mathrm{Va}$ male from each vial was crossed again with $2-3 \mathrm{Va} / \mathrm{Ba}$ virgin females. From each $\mathrm{F}_{2}$, males and virgin females of $\mathrm{Va}$ phenotype were crossed among them to obtain the next generation. In the $\mathrm{F}_{3}$ offspring, the rate between flies with normal phenotype and the total number of emerged flies was the measure of chromosomal viability. A chromosome was considered lethal if its viability in the homozygous condition was strictly zero. The lethal chromosomal lines could be maintained indefinitely by crossing the individuals among themselves. In the laboratory, $D$. subobscura flies were fed on a standard cornmeal-sugar-agar-yeast medium and all strains and crosses were kept under controlled conditions (at $19^{\circ} \mathrm{C}, 60 \%$ humidity, $12: 12 \mathrm{~h}$ light : dark cycle).

Four factorial ANOVAS were undertaken to examine the effect of population, year, month and altitude on the lethal frequencies. These were computed using Statistica v.6 (StatSoft Inc., Tulsa OK). The correlation coefficient between latitudes and lethal frequencies was calculated using the same statistical package. Lethal frequencies were normalized by the arcsine $\sqrt{q}$ transformation.

\section{RESULTS}

The lethal frequencies obtained in the Avala Mountain population in September 2003, 2004 and June of 2004, plus those from Petnica, Kamariste, Zanjic and Djerdap are presented in Table 1. No significant effect on lethal frequencies was observed for year, population, month or altitude of population (Table 2). The lethal frequencies of the Balkan populations (Petnica, Kamariste, Zanjic, Djerdap and Avala) did not correlate significantly with latitude $(r=0.1697, p$-value $=0.7850)$. This result was expected due to the low latitudinal range and the similarity in

Table 2. Statistical significance of the ANOVA analyses of population, year, month and altitude, respectively, on lethal frequencies in the Balkan D. subobscura populations

\begin{tabular}{l|c|c|c|c}
\hline \multicolumn{1}{c|}{ Effect } & d.f. & SS & $F$-ratio & $P$-value \\
\hline Population & 4 & 80.3889 & 2.30 & 0.2199 \\
Year & 6 & 93.2556 & 1.41 & 0.4717 \\
Month & 2 & 15.1822 & 0.45 & 0.6548 \\
Altitude & 3 & 42.9356 & 0.99 & 0.4692 \\
\hline
\end{tabular}

Note: $d . f$., degrees of freedom; SS, sums of squares; $F$-ratios and $P$-values are reported for all effects. 
Table 3. Lethal frequencies in D. subobscura Palearctic populations. Country, latitude, year of collection, habitat and sample size are also shown for each population

\begin{tabular}{|c|c|c|c|c|c|c|c|}
\hline Population & Country & Latitude & Year & Habitat & $N$ & Lethal freq. & Reference \\
\hline Umeå & Sweden & $63^{\circ} 50^{\prime} \mathrm{N}$ & 1990-92 & 6 & 23 & $0.04 \pm 0.04$ & [25] \\
\hline Hillevik & $»$ & $60^{\circ} 48^{\prime} \mathrm{N}$ & 1990-92 & 7 & 130 & $0.24 \pm 0.04$ & [25] \\
\hline Gävle & $»$ & $60^{\circ} 41^{\prime} \mathrm{N}$ & $1986-87$ & 8 & 68 & $0.31 \pm 0.06$ & {$[26]$} \\
\hline Helsinki & Finland & $60^{\circ} 10^{\prime} \mathrm{N}$ & $1981-82$ & 9 & 36 & $0.17 \pm 0.06$ & {$[26]$} \\
\hline Sunne & Sweden & $59^{\circ} 50^{\prime} \mathrm{N}$ & 1977 & 10 & 51 & $0.14 \pm 0.05$ & [27] \\
\hline Tvärminne & Finland & $59^{\circ} 49^{\prime} \mathrm{N}$ & $1981-82$ & 11 & 119 & $0.15 \pm 0.03$ & [26] \\
\hline Dröbak & Norway & $59^{\circ} 40^{\prime} \mathrm{N}$ & $1973-75$ & 12 & 132 & $0.20 \pm 0.04$ & [17] \\
\hline Ft. Augustus & Scotland & $57^{\circ} 14^{\prime} \mathrm{N}$ & 1979 & 13 & 101 & $0.10 \pm 0.03$ & [27] \\
\hline Tübingen & Germany & $48^{\circ} 31^{\prime} \mathrm{N}$ & $1975-78$ & 14 & 95 & $0.12 \pm 0.03$ & [27] \\
\hline Tulln (Vienna) & Austria & $48^{\circ} 20^{\prime} \mathrm{N}$ & $1973-75$ & 15 & 49 & $0.43 \pm 0.07$ & [17] \\
\hline Zernez & Switzerland & $46^{\circ} 43^{\prime} \mathrm{N}$ & 1978 & 16 & 96 & $0.10 \pm 0.03$ & {$[27]$} \\
\hline Kamariste & Serbia & $45^{\circ} 28^{\prime} \mathrm{N}$ & 1996 & 2 & 85 & $0.27 \pm 0.05$ & [22] \\
\hline Avala & » & $44^{\circ} 48^{\prime} \mathrm{N}$ & $2003-04$ & 5 & 80 & $0.22 \pm 0.05$ & $*$ \\
\hline Djerdap & » & $44^{\circ} 37^{\prime} \mathrm{N}$ & $2001-02$ & 4 & 152 & $0.29 \pm 0.04$ & [23] \\
\hline Petnica & » & $44^{\circ} 14^{\prime} \mathrm{N}$ & 1995 & 1 & 82 & $0.22 \pm 0.05$ & [22] \\
\hline Zanjic & Montenegro & $42^{\circ} 24^{\prime} \mathrm{N}$ & 1997 & 3 & 70 & $0.26 \pm 0.05$ & {$[22]$} \\
\hline Bordils & Spain & $42^{\circ} 02^{\prime} \mathrm{N}$ & 1984 & 17 & 131 & $0.29 \pm 0.04$ & [28] \\
\hline Moià (Barcelona) & $»$ & $41^{\circ} 48^{\prime} \mathrm{N}$ & 1982 & 18 & 70 & $0.31 \pm 0.06$ & {$[26]$} \\
\hline Barcelona & $»$ & $41^{\circ} 23^{\prime} \mathrm{N}$ & 2004 & 19 & 119 & $0.24 \pm 0.04$ & [29] \\
\hline Formia & Italy & $41^{\circ} 15^{\prime} \mathrm{N}$ & 1977 & 20 & 94 & $0.20 \pm 0.04$ & [27] \\
\hline Ponza & $»$ & $40^{\circ} 54^{\prime} \mathrm{N}$ & 1977 & 21 & 100 & $0.25 \pm 0.04$ & [27] \\
\hline Thessaloniki & Greece & $40^{\circ} 38^{\prime} \mathrm{N}$ & $1973-75$ & 22 & 420 & $0.17 \pm 0.02$ & [17] \\
\hline Kastoria & » & $40^{\circ} 31^{\prime} \mathrm{N}$ & $1973-75$ & 23 & 284 & $0.16 \pm 0.02$ & [17] \\
\hline Mt.Parnes & $»$ & $38^{\circ} 17^{\prime} \mathrm{N}$ & 1977 & 24 & 176 & $0.38 \pm 0.04$ & {$[30]$} \\
\hline Cinisi (Sicily) & Italy & $38^{\circ} 08^{\prime} \mathrm{N}$ & 1978 & 25 & 93 & $0.13 \pm 0.03$ & {$[27]$} \\
\hline Bizerte & Tunisia & $37^{\circ} 10^{\prime} \mathrm{N}$ & 1978 & 26 & 101 & $0.13 \pm 0.03$ & [27] \\
\hline Alikianou (Crete) & Greece & $35^{\circ} 27^{\prime} \mathrm{N}$ & 1977 & 27 & 145 & $0.32 \pm 0.04$ & {$[30]$} \\
\hline
\end{tabular}

Notes: N, sample size; *, current study. Collection dates for Dröbak, Ft. Augustus, Tulln (Vienna), Thessaloniki and Kastoria are approximate. Habitats: 1-5, see Table 1; 6, garden with apple trees and vegetable patches; 7, ash (Fraxinus) and pine (Pinus silvestris) forest with fescue grass (Festuca) undergrowth; 8, suburban orchard with apple trees (the apples were in heaps due to windfall) and alder (Alnus glutinosa) bushes; 9, urban setting with pine (Pinus silvestris) and birch (Betula verrucosa) trees, fescue grass undergrowth; 10, fir tree forest, garden land around the village; 11, hazel (Corylus avellana) and alder (Alnus glutinosa) bushes with some oak (Quercus robur) trees, the lower vegetation is lush and mixed; 12, mixed forest mixed forest of Acer and Picea; 13, Picea nigra forest; 14, mixed woodland near the town; 15, riparian forest of Alnus and Fagus; 16, alpine forest on slope of mountain; 17, black poplar forest (Populus nigra) and apple orchards; 18, ilex (Ouercus ilex) and Scots pine (Pinus sylvestris) forest; 19, sparse pine forest (Pinus pinea) with some ilex (Querceus ilex); 20, orange and lemon orchards, Mediterranean coastal vegetation; 21, orange and lemon orchards, Mediterranean coastal vegetation; 22, spruce forest (Picea) and sparse shrubs; 23, lush vegetation of beech (Fagus sylvatica), black pine (Pinus nigra) and fir trees (Abies); 24, fir forest (Abies cephallonica) with a few Crataegus and Prunus; 25, lemon trees, Mediterranean coastal vegetation; 26, orange trees, Mediterranean coastal vegetation; 27, orange orchards. 
lethal frequencies. General information on these Balkan populations was grouped with that from other Palearctic populations (Table 3 ). In this table, values for Mt. Avala and Djerdap show the average of the samples obtained in the different years. The lethal frequency presented for Hillevik is also the average of the 1990 and 1992 samples. Based on latitudinal location and lethal frequencies, it seems that the Serbian and Montenegrin populations are situated in the central area of distribution of the species. Usually, a population is considered to be central if its lethal frequency is equal to or higher than $0.2[31,32]$. Thus, populations from Tübingen to Mt. Parnes could be considered central, whereas those from Umeå to Ft. Augustus and from Cinisi to Alikianou could be classified as northern and southern marginal populations, respectively. However, in the central group some populations have lethal frequencies lower than 0.20: Tübingen, Zernez, Thessaloniki and Kastoria. On the contrary, some northern (Hillevik, Gävle and Dröbak) and southern (Alikianou) marginal populations have lethal frequencies equal to or higher than 0.20 .

\section{DISCUSSION}

A classical topic in population genetics has been the genetic variability within the distribution range of a species. A cornerstone in population variation is the inversion chromosomal polymorphism, which varies adaptively in time (over the seasons and years) and space (reviewed in [1, 4, 32-34]). In general, marginal populations present lower levels of variability than those located in the central area of the species distribution (for a review see [4, 35, 36]). However, not all genetic markers seem to follow this pattern [4]. In the case of lethal chromosomes, it has been accepted that D. willistoni has lower frequencies in marginal than in central populations [32], but this conclusion is not clear-cut [37]. In D. melanogaster, some geographical variation was found, but with different interpretations $[7,38-40]$. However, no differentiation among populations was observed in D. prosaltans [41]. Finally, lower frequencies of lethal genes were detected in isolated marginal populations of $D$. pseudoobscura [42].

The D. subobscura populations from Serbia and Montenegro appear to be situated in central area of the species distribution, because their lethal frequencies are higher than 0.2 . This was confirmed by their inversion chromosomal polymorphisms [43-45]. These populations form a homogeneous group regardless of their geographical location, habitat, altitude and year. Finally, lethal interpopulation allelism tests revealed intense gene flow between the populations [46], which probably homogenizes them. A similar situation was reported in Japanese D. melanogaster populations [47].

However, is the lethal chromosomal frequency actually a good marker for differentiating central from marginal populations? In $D$. subobscura it is consid- ered that marginal populations in the northern area of distribution are those located on the Scandinavian Peninsula (Norway, Sweden and Finland) [31, 32]. However, Hillevik and Gävle presented lethal frequencies over 0.2 (Table 3 ). In small marginal populations, rapid elimination of lethal genes is expected due to the high frequency of homozygotes. In Hillevik and Gävle, the absence of lethal allelism could be interpreted as both populations had a large effective population size, but this conflicts with the small sample sizes collected $[25,26]$. It is possible that the samples contained the remains of the genetic variability of a population expansion that took place some time ago [25] or were composed of migrants from different populations. In the southern area of distribution, it is generally accepted that populations located on the north Mediterranean coast are central and that those on the south coast are marginal [31, 32]. In terms of lethal frequency and geographical situation Bizerte is clearly a marginal population. However, the Greek populations from Kastoria and Thessaloniki present lethal frequencies under 0.2 (Table 3). Although the habitat from which the samples were collected seemed appropriate, the season was not consistent with the period of population expansion. In such circumstances, the effective size may be small whereas the probability of lethal chromosome elimination due to the homozygote condition may be high. The same hypothesis may also explain the low lethal frequency detected in Cinisi (Sicily) (Table 3). In the central area of the D. subobscura distribution only two anomalous lethal frequencies were observed, those for the Tübingen and Zernez populations [27]. The Tübingen sample was obtained from a good habitat for the species but at the end of the second period of population expansion. The Zernez population was an alpine population and its particular ecological conditions probably resulted in a small effective size.

In general, lethal chromosome frequencies are related to the effective population size. If the latter is large, most lethals will be in the heterozygous condition and will not be eliminated by selection. On the other hand, a small effective number implies that most lethal chromosomes could be in the homozygous condition and thus eliminated by selection. Central populations are usually large and present high lethal frequencies, and marginal populations, which are often small, usually show low lethal frequencies. This general pattern has been observed in D. subobscura $[17,25-$ $27,48]$, but some results require additional explanation. As shown in Table 3, habitat was not relevant, because all samples were collected in good conditions for the species. However, the period of collection could be important, because $D$. subobscura has two periods of expansion during the year, the most important in spring and the second less intense expansion in early autumn. Depending on the timing of sample collection the genetic structure of the population could differ and this could be reflected in the lethal frequencies. 
When populations were sampled during the first population expansion period (spring), the effective population size, measured by lethal allelism, was enormous and the lethal frequency was high [28-30]. When the population was sampled in the second expansion period (autumn), the effective population size was large, but not enormous, and the lethal frequencies were not as high [29]. The pattern of allelism also differed: whereas in spring most allelic cases were only due to independent pairs of lethals, in autumn some clusters and concatenamers of lethals were observed [29]. Even trapping in the first period of expansion, but at different points in time, could allow detection of the changes in genetic population structure. For instance, the Mt. Parnes sample trapped in April 1977 was collected at the peak of its expansion, deduced by its almost infinite population size and lethal frequency $(0.38 \pm 0.04$, Table 3). However, when the same population was collected again in May 2006, the weather was cooler than expected. The population was at the beginning of the expansion period, with a large effective population size (estimated between 11874 and 26828 individuals), but lower than that observed in 1977 [29]. Consequently, the lethal frequency was also smaller $(0.34 \pm \pm 0.04)$ than that in $1977(0.38 \pm 0.04)$.

Finally, American populations of D. subobscura can be considered as colonizing populations and not marginal. The colonizing event determined their genetic structure and evolution. In these populations, lethal frequencies are mainly dependent on heterotic or historical associations between lethal genes and chromosomal inversions $[49,50]$. Thus, as a general conclusion, lethal frequency seems to indicate particular situations in the genetic structure of a population.

\section{ACKNOWLEDGMENTS}

We thank Profs. A. Saura and D. Sperlich for their detailed description of the collecting sites. This study was supported by the following grants: number 173025 from the Ministry of Science and Technological Development of the Republic of Serbia; BFU2009-07564 from the Ministerio de Ciencia e Innovacio'n (Spain); and 2009 SGR 636 from the "Generalitat de Catalunya" (Spain). FM is a member of the IRBIO (Institut de Recerca de la Biodiversitat, Universitat de Barcelona). Finally, we also thank Dr. J. Ferrier (Servei d'Assessorament Lingüístic, Universitat de Barcelona) for corrections to the English.

\section{REFERENCES}

1. Dobzhansky, Th., Genetic of the evolutionary process, N.Y.: Columbia Univ. Press, 1970.

2. Lewontin, R.C., The Genetic Basis of Evolutionary Change, N.Y.: Columbia Univ. Press, 1974.

3. Wright, S., Evolution and the Genetics of Populations. Vol. 4. Variability within and among natural populations, Chicago: Univ. Chicago Press, 1978.
4. Powell, J.R., Progress and Prospects in Evolutionary Biology. The Drosophila Model, N.Y.: Oxford Univ. Press, Inc., 1997.

5. Mestres, F., Balanyà, J., Pascual, M., et al., Lethal genes and the colonization of America by Drosophila subobscura, Curr. Top. in Genet., 2005, vol. 1, pp. 31-57.

6. Ayala, F.J., Kiger J.A., Modern Genetics. Menlo Park, CA: Benjamin/Cummings Pub. Co. Inc., 1984.

7. Ives, P.T., Genetic changes in American populations of D. melanogaster, Proc. Natl Acad. Sci. USA, 1954, vol. 40, pp. 87-92.

8. Sperlich, D., Jaksch, G., Karlik, A., Recessive lethals in island and continental populations of D. melanogaster, Drosophila Inform. Serv., 1963, vol. 38, pp. 83.

9. Sturtevant, A.H., Autosomal lethals in wild populations of D. pseudoobscura, Biol. Bull., 1937, vol. 73, pp. 542-551.

10. Dobzhansky, Th., Queal, M.L., Genetics of natural populations. II. Genic variation in populations of D. pseudoobscura inhabiting isolated mountain range, Genetics, 1938, vol. 23, pp. 463-484.

11. Dobzhansky, Th., Holz, A.M., Spassky, B., Genetics of natural populations. V. Relations between mutation rate and accumulation of lethals in populations of D. pseudoobscura, Genetics, 1942, vol. 27, pp. 463490.

12. Band, H.T., Ives, P.T., Correlated changes in environmental and lethal frequency in a natural population of D. melanogaster, Proc. Natl Acad. Sci. USA, 1961, vol. 47 , pp. 180-185.

13. Choo, J.K., Lee, T.J., Genetic changes in a Korean population of D. melanogaster, Jpn. J. Genet., 1986, vol. 61, pp. 337-343.

14. Ives, P.T., Band, H.T., Continuing studies on the South Amherst D. melanogaster natural population during the 1970's and 1980's, Evolution, 1986, vol. 40, pp. 1289-1302.

15. Goldschmidt, E., Wahrman, J., Ledermann-Klein, A., et al., A two year survey of population dynamics in D. melanogaster, Evolution, 1955, vol. 9, pp. 353-366.

16. Merrel, D.J., Lethal frequency and allelism in DDT resistant populations and their controls, Amer. Nat., 1965, vol. 99, pp. 411-417.

17. Sperlich, D., Feuerbach-Mravlag, H., Lange, P., et al., Genetic load and viability distribution in central and marginal populations of D. subobscura, Genetics, 1977, vol. 86, pp. 835-848.

18. Mestres, F., Serra, L., The $V a / B a$ balanced lethal strain: Thirty years of research in Drosophila subobscura (1977-2007), J. Zool. Syst. Evol. Res., 2008, vol. 46, pp. 190-191.

19. Araúz, P.A., Pegueroles, C., Calabria, G., et al., Genetic markers of the $\mathrm{Va} / \mathrm{Ba}$ balanced lethal strain of Drosophila subobscura, Drosophila Inform. Serv., 2010, vol. 93, pp. 9-10.

20. Zivanovic, G., Mestres. F., Viabilities of D. subobscura homo- and heterokaryotypes at optimal and stress temperatures. I. Analysis over several years, Hereditas, 2010, vol. 147 , pp. $70-81$. 
21. Zivanovic, G., Mestres, F., Viabilities of D. subobscura homo- and heterokaryotypes at optimal and stress temperatures. II. Seasonal component analysis, Hereditas, 2010, vol. 147, pp. 82-89.

22. Zivanovic, G., Andjelkovic, M., Marinkovic, D., Genetic load and coadaptation of chromosomal inversions. II. O-chromosomes in Drosophila subobscura populations, Hereditas, 2000, vol. 133, pp. 105-113.

23. Zivanovic, G., Marinkovic, D., Viabilities of originally natural $\mathrm{O}$-chromosomal inversion homo- and heterokaryotypes in Drosophila subobscura, Hereditas, 2003, vol. 139, pp. 128-142.

24. Andjelkovic, M., Zivanovic, G., Milanovic, M., Genetic loads and coadaptivity of chromosomal inversions. I. Inversion polymorphism and genetic load on chromosome $\mathrm{O}$ in a $D$. subobscura population from Petnica, J. Zool. Syst. Evol. Res., 1998, vol. 36, pp. $123-128$.

25. Saura, A., Johansson, B., Lokki, J., et al., Genetic load in marginal populations of Drosophila subobscura, Hereditas, 1998, vol. 129, pp. 283-286.

26. Saura, A., Johansson, B., Eriksson, E., et al., Genetic load in northern populations of Drosophila subobscura, Hereditas, 1990, vol. 112, pp. 283-287.

27. Pfriem, P., Sperlich, D., Wild O chromosomes of Drosophila subobscura from different geographic regions have different effects on viability, Genetica, 1982, vol. 60, pp. 49-59.

28. Mestres, F., Pegueroles, G., Prevosti A., et al., Colonization of America by Drosophila subobscura: lethal genes and the problem of the $\mathrm{O}_{5}$ inversion, Evolution, 1990, vol. 44, pp. 1823-1836.

29. Arau'z, P.A., Mestres, F., Pegueroles, C., et al., Tracking the origin of the American colonization by Drosophila subobscura: genetic comparison between Eastern and Western Mediterranean populations, J. Zool. Syst. Evol. Res., 2009, vol. 47, pp. 25-34.

30. Loukas, M., Krimbas, C.B., Sourdis, J., The Genetics of Drosophila subobscura populations. XIII. A study of lethal allelism, Genetica, 1980, vol. 54, pp. 197-207.

31. Krimbas, C.B., The inversion polymorphism of Drosophila subobscura, Drosophila inversion polymorphism, eds Krimbas, C.B. and Powell, J.R., Boca Raton (Fl.): CRC Press Inc., 1992, pp. 127-220.

32. Krimbas, C.B., D. subobscura: Biology, Genetics and Inversion polymorphism, Hamburg; Verlag Dr. Kovac, 1993.

33. Sperlich, D., Pfriem, P., Chromosomal polymorphism in natural and experimental populations, The genetics and biology of Drosophila, eds Ashburner, M., Carson, H. L. and Thompson Jr., J. N., vol. 3e, N.Y.: Acad. Press, 1986, pp. 257-309.

34. Krimbas, C.B., Powell, J.R., Introduction, Drosophila inversion polymorphism, eds Krimbas, C.B. and Powell, J.R., Boca Raton (Fl.): CRC Press Inc., 1992, pp. $1-52$.

35. Carson, H.L., The genetic characteristics of marginal populations of Drosophila, Cold Spring Harb. Symp. Quant. Biol., 1955, vol. 20, pp. 276-287.
36. Soule', M., The epistasis cycle: A theory of marginal populations, Ann. Rev. Ecol. Syst., 1973, vol. 4, pp. $165-187$.

37. Townsend, J.I., Genetics of marginal populations of Drosophila willistoni, Evolution, 1952, vol. 6, pp. 428442.

38. Dubinin, N.P., On lethal mutations in natural populations, Genetics, 1946, vol. 31, pp. 21-38.

39. Hoenigsberg, H.F., de Navas, Y.G., Population genetics in the American tropics. I. Concealed recessives in different bioclimatic regions, Evolution, 1965, vol. 19, pp. 506-513.

40. Borai, F., David, J., Recessive lethals in Drosophila melanogaster from temperate and tropical habitats: a possible interaction with hybrid dysgenesis, Egypt. $J$. Genet. Cytol., 1983, vol. 12, pp. 65-78.

41. Dobzhansky, Th., Spassky, B., Genetics of natural populations. XXII. A comparison of concealed variability in Drosophila prosaltans with that in other species, Genetics, 1954, vol. 39, pp. 472-487.

42. Dobzhansky, Th., Hunter, A.S., Pavlovski, O., et al., Genetics of natural populations. XXXI. Genetics of an isolated marginal population of Drosophila pseudoobscura, Genetics, 1963, vol. 48, pp. 91-103.

43. Zivanovic, G., Milanovic, M., Andjelkovic, M., Chromosomal inversion polymorphism of Drosophila subobscura populations from Jastrebac Mountain shows temporal and habitat-related changes, J. Zool. Syst. Evol. Res., 1995, vol. 33, pp. 81-83.

44. Zivanovic, G., Andjelkovic, M., Marinkovic, D., Chromosomal inversion polymorphism of Drosophila subobscura from south-eastern part of Europe, J. Zool. Syst. Evol. Res., 2002, vol. 40, pp. 201-204.

45. Zivanovic, G., Seasonal changes in chromosomal inversion polymorphism in a Drosophila subobscura natural population from Southeastern European continental refugium of the last glaciation period, Russ. $J$. Genetics, 2007, vol. 43, no. 12, pp. 1344-1349.

46. Zivanovic, G., Arenas, C., Mestres, F., The genetic structure of Balkan populations of D. subobscura, Hereditas, 2007, vol. 144, pp. 120-128.

47. Yamazaki, T., Choo, J.-K., Watanabe, T.K., et al., Gene flow in natural populations of Drosophila melanogaster with special reference to lethal allelism rates and protein variation, Genetics, 1986, vol. 113, pp. 73-89.

48. Kohonen-Corish, M., Lokki, J., Saura, A., et al., The genetic load in a northern marginal population of Drosophila subobscura, Hereditas, 1985, vol. 102, pp. 255-258.

49. Mestres, F., Balanyà, J., Arenas, C., et al., Colonization of America by D. subobscura: Heterotic effect of chromosomal arrangements revealed by the persistence of lethal genes, Proc. Natl Acad. Sci. USA, 2001, vol. 98, pp. 9167-9170.

50. Mestres, F., Balanyà, J., Pascual, M., et al., Evolution of Chilean colonizing populations of Drosophila subobscura: lethal genes and chromosomal arrangements, Genetica, 2009, 136, pp. 37-48. 


\title{
ЧАСТОТЫ ЛЕТАЛЬНЫХ О-ХРОМОСОМ В ПОПУЛЯЦИЯХ Drosophila subobscura СЕРБИИ И ЧЕРНОГОРИИ
}

\author{
Г. Живанович 1 , С. Аренас ${ }^{2}$, Ф. Местрес ${ }^{3}$ \\ ${ }^{1}$ Department of Genetics, Institute for Biological Research "Sinisa Stankovic”, University of Belgrade 11000, Serbia \\ e-mail: goranziv@ibiss.bg.ac.rs \\ ${ }^{2}$ Departament d'Estadística, Universitat de Barcelona, Barcelona 08071, Spain \\ ${ }^{3}$ Departament de Genètica, Universitat de Barcelona, Barcelona 08071, Spain
}

\begin{abstract}
Частоты летальных мутаций О-хромосомы определили в трех выборках из популяции Drosophila subobscura горы Авала (Сербия), собранных в сентябре 2003 г. (0.218), июне 2004 г. (0.204) и сентябре 2004 г. (0.250). Эти оценки, а также оценки соответствующих частот мутаций в других балканских популяциях вида (Петница, Камаристе, Занжич и Джердап) использованы для анализа возможного эффекта популяции, года, месяца и высоты над уровнем моря на частоты летальных хромосом. Дисперсионный анализ не выявил эффектов данных факторов. Кроме того, показано отсутствие широтной изменчивости частоты летальных хромосом. Возможно, это объясняется географической близостью данных популяций и интенсивным генным обменом между ними. Результаты комплексного исследования палеарктических популяций Drosophila subobscura указывают на то, что балканские популяции данного вида расположены в центральной области ареала. Возможно, наблюдаемая частота летальных хромосом зависит от генетической структуры данных популяций.
\end{abstract}

